Abstract-Anthropogenic perturbations during the 19th and 20th centuries resulted in major declines in abundance of populations of shortnose sturgeon (Acipenser brevirostrum). Despite the designation of this species as endangered, most populations are still not recovering. Abundance monitoring is needed to identify fluctuations in recruitment and survival; however, river-specific assessments are deficient throughout the range of this species. During the summer of 2011, we used anchored nets to fish a closed population of shortnose sturgeon in the Altamaha River in Georgia. Markrecapture tagging resulted in the capture of 288 shortnose sturgeon (272 fish with unique marks and 16 fish recaptured) over 11 weekly sampling occasions. Estimates of the abundance of shortnose sturgeon were derived by using Huggins closed-capture models. The preferred model incorporated effects of temporal variation on weekly capture probability and estimated an abundance of 2218 individuals (95\% confidence interval [CI]: 1424-3350), including 725 (95\% CI: 455-1192) juveniles and 1493 (95\% CI: 954-2409) adults. Point estimates of group abundance indicate that the population is dominated by adults, although dynamic shifts in size structure following periods of high recruitment have been reported to occur. This study continued previous mark-recapture efforts in this river system, and its results offer further evidence that the Altamaha River supports the largest population of shortnose sturgeon south of Chesapeake Bay.

Manuscript submitted 9 March 2020. Manuscript accepted 19 June 2020. Fish. Bull. 118:198-204 (2020). Online publication date: 6 July 2020 . doi: 10.7755/FB.118.2.8

The views and opinions expressed or implied in this article are those of the author (or authors) and do not necessarily reflect the position of the National Marine Fisheries Service, NOAA.

\title{
Abundance of endangered shortnose sturgeon (Acipenser brevirostrum) in the Altamaha River in Georgia
}

\author{
Evan C. Ingram (contact author) \\ Douglas L. Peterson (retired) \\ Adam G. Fox
}

Email address for contact author: evan.ingram@stonybrook.edu

Warnell School of Forestry and Natural Resources

University of Georgia

180 East Green Street

Athens, Georgia 30602

Present address for contact author: School of Marine and Atmospheric Sciences

Stony Brook University

Stony Brook, New York 11790

The shortnose sturgeon (Acipenser brevirostrum) is an imperiled species that is widely distributed along the Atlantic seaboard of the United States (Vladykov and Greeley, 1963; Birstein, 1993; Kynard, 1997; NMFS, 1998). Overfishing, pollution, and habitat fragmentation during the 19th and 20th centuries led to range-wide declines in abundance and extirpations of populations of shortnose sturgeon (Dadswell, 1979). In 1967, this species was listed as endangered under the U.S. Endangered Species Preservation Act (Federal Register, 1967) and is currently protected under the U.S. Endangered Species Act of 1973. Shortnose sturgeon are listed as a single, range-wide stock, and each riverine population of this stock is separately managed; however, regulatory authorities recognize 5 regional population clusters, some of which may function as metapopulations (SSSRT, 2010). Despite decades of conservation efforts, the historical range of rivers occupied by this species is greatly reduced, and assessments that indicate recovery are rare (SSSRT, 2010; but see Bain et al., 2007).

Management of shortnose sturgeon is made difficult by a complex life history characterized by slow growth, delayed maturation, and longevity. Latitudinal differences in growth between river populations are well-documented, and the maximum age for southern populations of shortnose sturgeon (i.e., population segments south of Chesapeake Bay) has been reported as 20 years (Rogers and Weber ${ }^{1}$; Fleming et al., 2003), compared with the ages of northern populations that may reach 70 years (Dadswell, 1979). Likewise, although lengths at maturity of shortnose sturgeon are similar throughout their range, increased growth rates in southern river systems result in earlier ages at maturity and truncated life histories (Dadswell, 1979; Dadswell et al., 1984). Because of the difficulty of differentiating sex and maturity of fish in field conditions, a criterion of $500 \mathrm{~mm}$ fork length (FL) is commonly used to assign maturity for wild caught fish (Bain, 1997). Juveniles

\footnotetext{
${ }^{1}$ Rogers, S. G., and W. Weber. 1995. Movements of shortnose sturgeon in the Altamaha River System, Georgia, 78 p. Georgia Dep. Nat. Resour., Brunswick, GA. [Available from Georgia Dep. Nat. Resour., 2 Martin Luther King Jr. Dr. SE, Ste. 1252, Atlanta, GA 30334.]
} 
and adults inhabit narrow reaches near the freshwatersaltwater interface of their natal rivers during the spring and summer months, dispersing upstream for spawning or foraging purposes during winter and early spring (Hall et al., 1991). Clinal differences in temperature and discharge gradients appear to be the main factors influencing river use and the timing of upstream dispersal (Hall et al., 1991; Rogers and Weber ${ }^{1}$; Kieffer and Kynard, 1996; Ingram and Peterson, 2018).

Current objectives for management of shortnose sturgeon are aimed at recovery of populations to minimum thresholds of population size that would allow for eventual delisting (NMFS, 1998). Because of the marked absence of historical abundance data, research must prioritize efforts to define and evaluate listing criteria for contemporary populations. The largest and best-studied populations of shortnose sturgeon occur in the Hudson River in New York (56,708 adults; Bain et al., 2007) and in the Delaware River in Delaware and New Jersey ( 13,000 adults; O’Herron et al., 1993). Assessments of this species are lacking for most rivers south of the Chesapeake Bay; however, results of recent studies indicate that southern populations are particularly susceptible to declines in abundance because of their accelerated life cycle and lower abundances (Peterson and Farrae, 2011; Peterson and Bednarski, 2013; Bahr and Peterson, 2017). Therefore, the systematic monitoring of southern populations may be particularly important to identify fluctuations in annual recruitment or adult survival over multiple years.

In contrast to most large river systems along the Atlantic coast, the Altamaha River, in Georgia, is a relatively undisturbed habitat with one of the largest populations of shortnose sturgeon in the southeastern United States (NMFS, 1998; SSSRT, 2010). As such, it provides a rare opportunity to study population dynamics of shortnose sturgeon at the southern extent of the range of this species. Monitoring of the population in the Altamaha River from 2004 through 2010 identified shifts in size structure that were characterized by variable abundance of juveniles and stable abundance of adults (Peterson and Bednarski, 2013). Because southern populations may be particularly sensitive to point disturbances, continued assessments are necessary to evaluate changes in annual recruitment or adult survival. Consequently, the objectives of this study were to provide updated estimates of abundance for the population of shortnose sturgeon in the Altamaha River to complement previous work in this system.

\section{Materials and methods}

\section{Study area}

The Altamaha River is formed by the confluence of the Oconee and Ocmulgee Rivers and flows in a southeasterly direction for $207 \mathrm{~km}$ to its mouth at the Atlantic Ocean, which we designated as river kilometer (rkm) 0 (Fig. 1). The location of the interface of freshwater and saltwater varies depending on flow but is typically found between rkm 35 and 50 (Rogers and Weber ${ }^{1}$ ); tidal influence can persist as far as $60 \mathrm{rkm}$ upstream from the mouth (Sheldon and Alber, 2002). The main channel of the Altamaha River has no impoundments below the fall line, allowing shortnose sturgeon to access a variety of habitats throughout their life history. Although juveniles and spawning adults have been documented near the confluence and in both tributaries of the Altamaha River, the Oconee and Ocmulgee Rivers, during the winter months, the estuary represents the primary habitat of shortnose sturgeon (Ingram and Peterson, 2018). During summer, individuals are primarily limited to deepwater areas of the main channel near the freshwater-saltwater interface (Rogers and Weber ${ }^{1}$; Peterson and Bednarski, 2013; Ingram and Peterson, 2018).

\section{Capture and tagging}

All methods for the capture and handling of shortnose sturgeon in this study were performed in accordance with relevant guidelines and regulations and were authorized by the National Marine Fisheries Service (endangered species permit no. 16482), Georgia Department of Natural Resources (scientific collecting permit no. 13791), and University of Georgia Institutional Animal Care and Use Committee (animal use protocol no. A2013 01-012-R1).

From May through August 2011, shortnose sturgeon were targeted in the Altamaha River estuary with anchored monofilament gill nets and trammel nets. Nets were deployed in the tidally influenced reach of the estuary, with the majority of sampling effort occurring below the freshwater-saltwater interface (rkm 10-35). Cleanbottom sites for netting were identified from prior studies in the system (e.g., Peterson and Bednarski, 2013; Ingram and Peterson, 2018) and were confirmed with sonar. All nets measured $91.4 \mathrm{~m}$ long and $3.1 \mathrm{~m}$ deep. Gill nets were constructed of 3 randomly ordered $30.5-\mathrm{m}$ panels of monofilament meshes with stretch measures of 7.6, 10.2, and $15.3 \mathrm{~cm}$. Trammel nets had an inner panel of 7.6- $\mathrm{cm}$ mesh surrounded by 2 outer panels of 30.5-cm mesh. Nets were fished perpendicular to the river channel for 30-60 min during slack tides to maximize capture efficiency and minimize gear damage.

Shortnose sturgeon were identified and distinguished from sympatric species according to the descriptions of Vladykov and Greeley (1963) and Scott and Crossman (1973). Captured fish were immediately transferred to a floating net pen $(1.0 \times 1.5 \times 0.5 \mathrm{~m})$ and allowed to recover until netting activities were completed. Fork length, total length, and weight were recorded, and fish were examined for internal and external tags. If no tags were found, a uniquely coded passive integrated transponder tag was inserted into the body musculature beneath the 4 th dorsal scute. Once tagged, fish were released at their original capture site.

\section{Mark-recapture analyses}

Abundance estimates for juvenile and adult cohorts of shortnose sturgeon were derived by using Huggins closed-capture $p$ and $c$ models (Huggins, 1989, 1991). All 


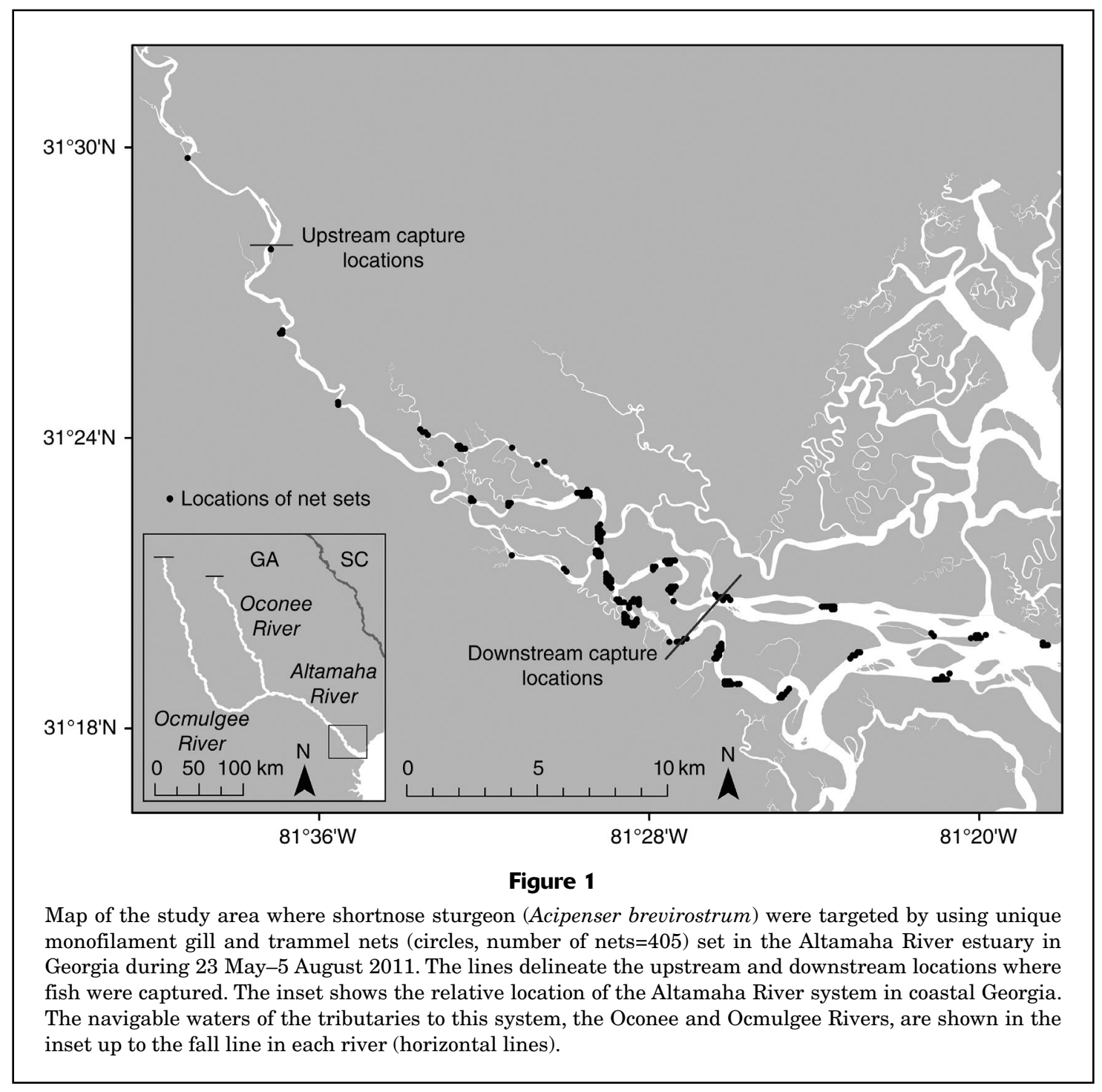

models sourced the program MARK (White and Burnham, 1999) through the package RMark (vers. 2.2.7; Laake $^{2}$ ) in $\mathrm{R}$ (vers. 3.5.1; R Core Team, 2018). Age assignments for shortnose sturgeon from length-frequency histograms are typically inextricable beyond age 1 because of increasing overlap in distribution with age (Fig. 2) (e.g., Dadswell et al., 1984; Kynard, 1997; Peterson and Farrae, 2011; Peterson and Bednarski, 2013); therefore, fish were identified as either juveniles $(<500 \mathrm{~mm}$ FL) or adults $(\geq 500 \mathrm{~mm} \mathrm{FL}$ ) on the basis of length at capture. Based on mark-recapture sampling, individual capture histories were constructed in $\mathrm{R}$ and were used as input data to fit models containing parameters for capture and recapture probability. Weekly sampling occasions were chosen to

\footnotetext{
${ }^{2}$ Laake, J. L. 2013. RMark: an R interface for analysis of capturerecapture data with MARK. Alaska Fish. Sci. Cent., AFSC Processed Rep. 2013-01, 25 p. Alaska Fish. Sci. Cent., Natl. Mar. Fish. Serv., NOAA, Seattle, WA. [Available from website.]
}

ensure that marked fish could randomly mix with unmarked fish before potential capture in subsequent sampling periods (Conroy and Carroll, 2009; Peterson and Bednarski, 2013).

Candidate models that assumed constant capture probability $\left(M_{0}\right)$, time-varying capture probabilities $\left(M_{\mathrm{t}}\right)$, group effects $\left(M_{\mathrm{g}}\right)$, or both time-varying capture probabilities and group effects $\left(M_{\mathrm{tg}}\right)$ were compared by using formal model selection methods. The relative weight of evidence for each specific model was evaluated by using the Akaike's information criterion corrected for small sample sizes (AICc; Hurvich and Tsai, 1989), as described by Burnham and Anderson (2002). For all models, the capture probability of marked and unmarked individuals was set as equal because of a low recapture rate (i.e., below $50 \%$ ). Sampling was limited to the latespring and summer months when the population was assumed closed (Peterson and Bednarski, 2013; Ingram and Peterson, 2018). 


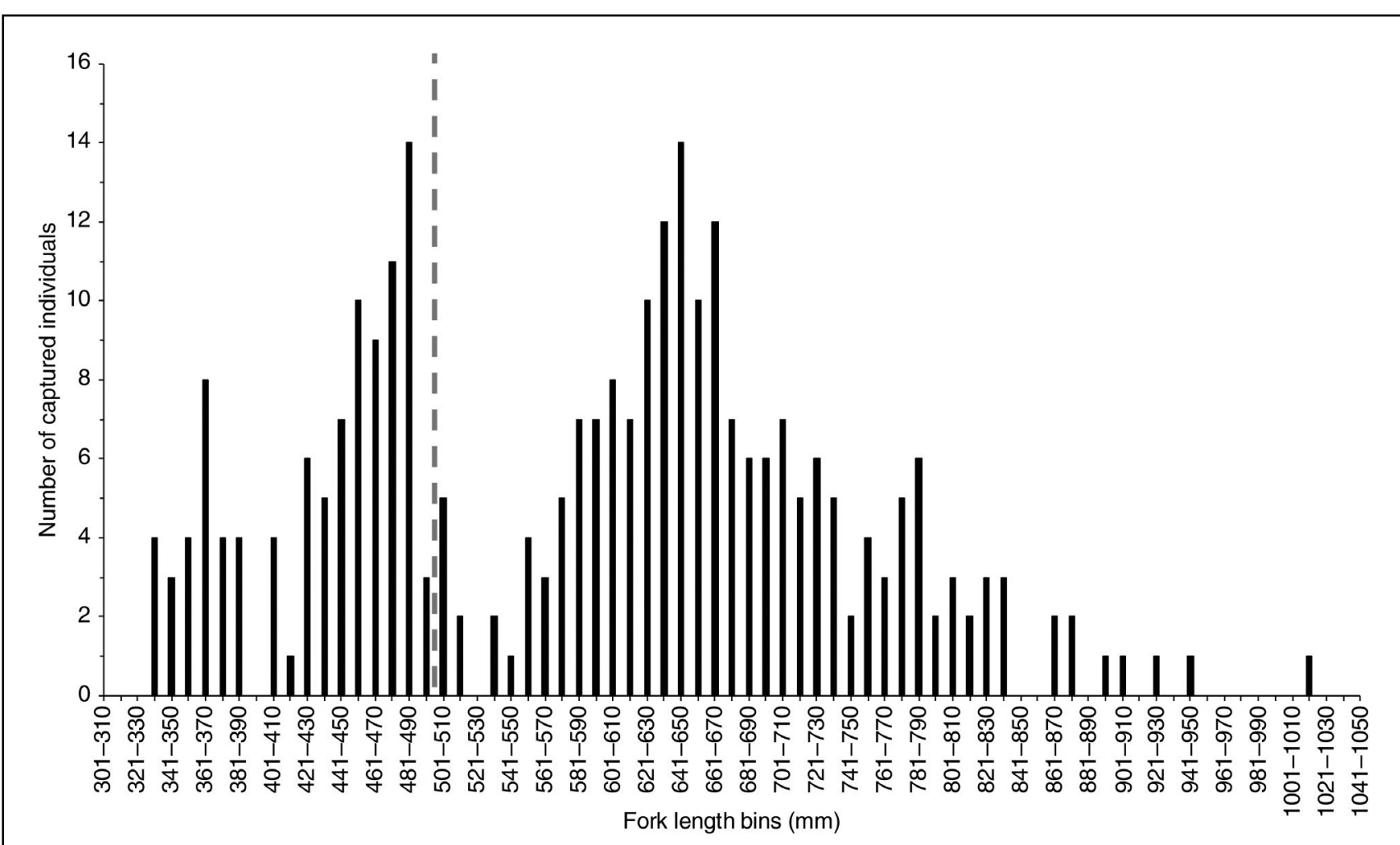

Figure 2

Length-frequency histogram of the number of shortnose sturgeon (Acipenser brevirostrum) that were captured in the Altamaha River in Georgia during 23 May-5 August 2011 (number of captured fish $[n]=288$ ). The vertical dashed line indicates the fork length used to separate juveniles $(<500 \mathrm{~mm}, n=96)$ from adults $(\geq 500 \mathrm{~mm}, n=192)$.

\section{Results}

During 2011, shortnose sturgeon were targeted with a total of 405 individual nets deployed for a total of 244.3 net hours. Sampling occurred Monday-Friday with a mean effort of 22.2 net hours/week (standard deviation [SD] 5.4), within a range of 14.2-30.9 net hours/week, over 11 weekly sampling periods from 23 May to 5 August. Net soak time ranged from 0.16 to $1.97 \mathrm{~h}$, and the mean soak time was $0.61 \mathrm{~h}$ (SD 0.25). Netting efforts resulted in the take of 288 shortnose sturgeon, including 96 juveniles (89 fish with unique marks and 7 fish recaptured) and 192 adults (183 fish with unique marks and 9 fish recaptured) (Table 1), with capture rates of $0-19$ individuals/net and a mean capture rate of 0.71 individuals/net (SD 1.70). Length of captured fish ranged from 332 to $1015 \mathrm{~mm} \mathrm{FL}$, with a mean of $595.12 \mathrm{~mm}$ FL (SD 140.67). Of the 272 unique fish encountered, 12 shortnose sturgeon were recaptured once during a later weekly occasion and 2 fish were recaptured twice. The total recapture rate of tagged fish over the course of the study was $5.6 \%$ (16 of 272 fish recaptured).

Results of model selection provide strong evidence for the top-ranked model based on our mark-recapture data (Table 2). The preferred model $\left(M_{\mathrm{t}}\right.$; number of parameters: 11) from evaluation with the $\mathrm{AIC} c$ is the model that incorporated effects of temporal variation on weekly capture probability of shortnose sturgeon. This model comprised $\sim 99 \%$ of the weight in the data set and was 100 times more likely to be the best model than the second-ranked model. There was essentially no support for the remaining candidate models that assumed constant capture probability or included group effects (i.e., relative difference in AICc values between the best model and each candidate model was $>10$ ).

Estimates of abundance for shortnose sturgeon were determined on the basis of the AIC $c$-preferred model for capture probability $\left(M_{\mathrm{t}}\right)$. Modeling yielded a total point estimate of 2218 shortnose sturgeon (standard error [SE] 527.7; 95\% CI: 1424-3350), with juvenile abundance of 725 individuals (SE 182.5; 95\% CI: 455-1192) and adult abundance of 1493 individuals (SE 361.0; 95\% CI: 954-2409). The assumption of a closed population was considered valid because regular sampling immediately upstream and downstream of the estuary reach in the study area did not result in capture of fish and indicated that violations of closure did not occur or were rare (Fig. 1). Two individual fish were determined to have died during sampling procedures; these fish with known fates were incorporated into the modeling framework during the construction of the capture histories (Table 1). 


\section{Table 1}

Weekly sampling effort and number of juvenile $(<500 \mathrm{~mm}$ fork length [FL]) and adult ( $\geq 500 \mathrm{~mm}$ FL) shortnose sturgeon (Acipenser brevirostrum) captured and recaptured in the Altamaha River in Georgia during the summer of 2011.

\begin{tabular}{|c|c|c|c|c|c|c|}
\hline \multirow[b]{2}{*}{ Sampling period } & \multirow{2}{*}{$\begin{array}{l}\text { Total no. of } \\
\text { nets set }\end{array}$} & \multirow[b]{2}{*}{ Net hours } & \multicolumn{2}{|c|}{ Juvenile } & \multicolumn{2}{|c|}{ Adult } \\
\hline & & & Captured & Recaptured & Captured & Recaptured \\
\hline May 23-29 & 30 & 28.4 & 15 & 0 & 22 & 1 \\
\hline May 30-June 5 & 44 & 28.9 & 9 & 1 & $16^{\mathrm{a}}$ & 1 \\
\hline June 6-12 & 46 & 30.9 & 8 & 1 & 33 & 1 \\
\hline June 13-19 & 36 & 19.0 & 3 & 0 & 12 & 1 \\
\hline June 20-26 & 36 & 19.4 & 7 & 2 & 18 & 0 \\
\hline June 27-July 3 & 38 & 22.0 & 4 & 1 & 8 & 2 \\
\hline July 4-10 & 43 & 24.9 & 20 & 2 & $25^{\mathrm{a}}$ & 1 \\
\hline July 11-17 & 33 & 15.8 & 2 & 0 & 5 & 0 \\
\hline July 18-24 & 35 & 20.1 & 11 & 0 & 13 & 1 \\
\hline July $25-31$ & 36 & 20.8 & 6 & 0 & 17 & 1 \\
\hline August 1-7 & 28 & 14.2 & 11 & 0 & 23 & 0 \\
\hline Total & 405 & 244.3 & 96 & 7 & 192 & 9 \\
\hline
\end{tabular}

\section{Table 2}

Evaluation of the Huggins closed-capture candidate models used to describe variation in capture probability of juvenile and adult cohorts of shortnose sturgeon (Acipenser brevirostrum) in the Altamaha River, Georgia, from 23 May to 5 August 2011. Results include Akaike information criterion corrected for small sample size (AICc), difference in $\mathrm{AIC} c$ between models $(\triangle \mathrm{AIC} c)$, Akaike weight $\left(w_{\mathrm{i}}\right)$, and the number of parameters $(K)$ estimated for each model. The AICc-preferred model $\left(M_{\mathrm{t}}\right)$ incorporated the effects of temporal variation on weekly capture probability.

\begin{tabular}{lcrcc}
\hline Capture probability & AIC $c$ & $\Delta$ AIC $c$ & $w_{\mathrm{i}}$ & $K$ \\
\hline Time $\left(M_{\mathrm{t}}\right)$ & 1439.73 & 0.00 & 0.99 & 11 \\
Time and group & 1449.88 & 10.15 & 0.01 & 22 \\
$\quad$ interaction $\left(M_{\mathrm{tg}}\right)$ & & & & \\
$\quad$ Constant $\left(M_{0}\right)$ & 1480.50 & 40.78 & 0.00 & 1 \\
Group $\left(M_{\mathrm{g}}\right)$ & 1481.72 & 41.99 & 0.00 & 2 \\
& & & &
\end{tabular}

\section{Discussion}

Population assessments remain a key research need because of their usefulness in efforts to quantify and examine the recovery of endangered shortnose sturgeon (NMFS, 1998; SSSRT, 2010). Here, we provide new information regarding demographics of shortnose sturgeon in the Altamaha River during 2011. Specifically, we estimated abundance of juveniles (725 individuals) and adults (1493 individuals) from applied mark-recapture sampling and with capture-recapture models. These abundance data add to our knowledge of this population of shortnose sturgeon and are necessary to inform development of management strategies for ensuring long-term population survival.

Conditional likelihood methods, such as the Huggins closed-capture model, are powerful tools for estimating abundance from individual encounter probabilities (Huggins, 1989, 1991). However, the validity of these parameter estimates is dependent on the underlying model assumptions, specifically that 1 ) the population is closed and 2) all individuals have equal capture probability (Conroy and Carroll, 2009). To minimize any inherent uncertainty in the models and to ensure that these assumptions were met, we used a sampling design consistent with previous work (i.e., Peterson and Bednarski, 2013). Although the assumption of closure is difficult to validate, the lack of captures beyond the study area, as well as limited evidence of upriver movements from acoustic telemetry detections, is consistent with the assumption that the population was closed during the sampling period (see Ingram and Peterson, 2018). Likewise, there appears to be no bias of size selection on capture probability for shortnose sturgeon in the Altamaha River (Peterson and Bednarski, 2013), and model selection results provide no evidence for group effects on capture probability between juveniles and adults.

Estimates of abundance from the time-varying captureprobability model indicate that the Altamaha River continues to support one of the largest and most persistent populations of shortnose sturgeon in the southeastern United States. However, the overall dearth of quantified assessments for other southern systems makes riverspecific comparisons difficult. Analogous studies of southern populations that exceed 1000 individuals have been done only in the Savannah River in Georgia and South 
Carolina (Bahr and Peterson, 2017) and in the Pee Dee River in North Carolina and South Carolina (Kynard, 1997). For the population in the Altamaha River, Peterson and Bednarski (2013) reported point estimates of annual abundance in a range of 1206-5551 individuals during summer in 2004-2010, with a between-year coefficient of variation in the river system of up to $56.6 \%$. The noted disparity of estimates between years for the relatively undisturbed population in Altamaha River indicates that such cyclic variation is normal but may be evident only on temporal scales beyond the typical research cycle of 1-3 years. As such, we suggest that continued long-term monitoring of populations of shortnose sturgeon is necessary to develop indices of abundance and, ultimately, define management goals for recovery.

Observed demographics from our study are consistent with previously described trends and add to the multiyear data series available for shortnose sturgeon in the Altamaha River (Peterson and Bednarski, 2013). Our results indicate that the Altamaha River population continues to be largely dominated by adults, likely in response to the observed shift from a juvenile-dominated structure to one dominated by adults, following 3 years of sustained drought in 2008-2010 (Peterson and Bednarski, 2013). Variable juvenile recruitment, coupled with a relatively stable adult abundance over several years, has been attributed to rapid adult turnover following periods of high recruitment, such as the level that was observed in 2004-2007 (Peterson and Farrae, 2011; Peterson and Bednarski, 2013). The shifts in annual population structure that are readily apparent from these uninterrupted data are likely a result of the response of populations of shortnose sturgeon to stochastic environmental events (Buckley and Kynard, 1985; Jenkins et al., 1993; Rogers and Weber ${ }^{1}$; Woodland and Secor, 2007). As such, sustained annual monitoring may be the only way to reliably inform or evaluate management efforts for this population.

The results of this study further indicate the viability of mark-recapture methods for sampling populations of shortnose sturgeon. Although labor intensive, these methods are relatively simple to implement and provide data that can yield robust demographic estimates-particularly for populations in southern systems for which the model assumptions of closure can be met over relatively short sampling periods. Furthermore, these methods can be applied over multiyear studies to generate long-term, standardized data sets necessary for the management of long-lived species. The success of comparable multiyear mark-recapture studies of large populations of shortnose sturgeon, such as those in the Hudson River in New York (Bain et al., 2007) and in the Savannah River in Georgia (Bahr and Peterson, 2017), indicates that a standardized mark-recapture method could be strategically implemented on a coast-wide scale. However, no other populations of shortnose sturgeon have been studied on the temporal scale used to evaluate the population in the Altamaha River, for which annual estimates are available over an uninterrupted period from 2004 through 2011 from this study and another (Peterson and Bednarksi, 2013).
The utility of hydroacoustic tools to estimate abundance has been recently demonstrated for the sympatric Atlantic sturgeon (Acipenser oxyrinchus oxyrinchus) during spawning runs in rivers in New York, North Carolina, and South Carolina (Flowers and Hightower, 2015; Vine et al., 2019; Kazyak et al., 2020). Although methods that incorporate acoustic telemetry are appropriate for endangered species and benefit from being largely passive, they are currently impractical for use with shortnose sturgeon in southern river systems. Because of the logistical constraints inherent in acoustic tagging studies, sample sizes are often too small to reliably estimate abundance for a representative proportion of tagged fish (e.g., Ingram and Peterson, 2018). Likewise, the size selectivity of side-scan sonar is limited by current technological capabilities and only larger fish ( $>40 \mathrm{~cm}$ FL) can be reliably identified (Andrews et al., 2020).

The overall findings of this study have important implications for species recovery and build upon previous mark-recapture derived estimates of abundance and recruitment for shortnose sturgeon. Quantification of population demographics is a prerequisite for the accurate assessment of recovery. Although marked clinal variation among stocks of shortnose sturgeon in rivers illustrates the need to manage this species as distinct population segments, the interannual variability in demographics and recruitment of these stocks underscores the need for long-term monitoring to develop regionally specific goals for recovery. Continuation of this research within the Altamaha River is necessary to further population recovery and viability-particularly to refine threshold points for the minimum population size that can be used to evaluate the appropriateness of listing status under the Endangered Species Act and to facilitate the allocation of resources.

\section{Acknowledgments}

Funding for this project was provided by the National Marine Fisheries Service and administered by the Georgia Department of Natural Resources. We are especially grateful to R. Harrell and J. Garritt, both of whom provided field assistance that was critical to the success of this project. We also thank M. Bednarski and D. Higginbotham for assistance with preliminary data analyses and the administration of field logistics.

\section{Literature cited}

Andrews, S. N., A. M. O'Sullivan, J. Helminen, D. F. Arluison, K. M. Samways, T. Linnansaari, and R. A. Curry.

2020. Development of active numerating side-scan for a high-density overwintering location for endemic shortnose sturgeon (Acipenser brevirostrum) in the Saint John River, New Brunswick. Diversity 12:23. Crossref

Bahr, D. L., and D. L. Peterson.

2017. Status of shortnose sturgeon population in the Savannah River, Georgia. Trans. Am. Fish. Soc. 146:92-98. Crossref 
Bain, M. B.

1997. Atlantic and shortnose sturgeons of the Hudson River: common and divergent life history attributes. Environ. Biol. Fish. 48:347-358. Crossref

Bain, M. B., N. Haley, D. L. Peterson, K. K. Arend, K. E. Mills, and P. J. Sullivan.

2007. Recovery of a US endangered fish. PLoS ONE 2(1):e168. Crossref

Birstein, V. J.

1993. Sturgeons and paddlefishes: threatened fishes in need of conservation. Conserv. Biol. 7:773-787. Crossref

Buckley, J., and B. Kynard.

1985. Habitat use and behavior of pre-spawning and spawning shortnose sturgeon, Acipenser brevirostrum, in the Connecticut River. In North American sturgeons: biology and aquaculture potential (F. P. Binkowski and S. I. Doroshov, eds.), p. 111-117. Dr. W. Junk Publishers, Dordrecht, Netherlands.

Burnham, K. P., and D. R. Anderson.

2002. Model selection and multimodel inference: a practical information-theoretic approach, 2nd ed., 488 p. SpringerVerlag, New York.

Conroy, M. J., and J. P. Carroll.

2009. Quantitative conservation of vertebrates, $352 \mathrm{p}$. WileyBlackwell, Hoboken, NJ.

Dadswell, M. J.

1979. Biology and population characteristics of the shortnose sturgeon, Acipenser brevirostrum LeSueur 1818 (Osteichthyes: Acipenseridae), in the Saint John River estuary, New Brunswick, Canada. Can. J. Zool. 57:2186-2210. Crossref

Dadswell, M. J., B. D. Taubert, T. S. Squiers, D. Marchette, and

J. Buckley.

1984. Synopsis of biological data on shortnose sturgeon, Acipenser brevirostrum LeSueur 1818. NOAA Tech. Rep. NMFS 14, $45 \mathrm{p}$.

Federal Register.

1967. Native fish and wildlife: endangered species. 32:4001. [Available from website.]

Fleming, J. E., T. D. Bryce, and J. P. Kirk.

2003. Age, growth, and status of shortnose sturgeon in the lower Ogeechee River, Georgia. Proc. Annu. Conf. Southeast. Assoc. Fish Wildl. Agencies 57:80-91.

Flowers, H. J., and J. E. Hightower.

2015. Estimating sturgeon abundance in the Carolinas using side-scan sonar. Mar. Coast. Fish. 7:1-9. Crossref

Hall, J. W., T. I. J. Smith, and S. D. Lamprecht.

1991. Movements and habitats of shortnose sturgeon Acipenser brevirostrum in the Savannah River. Copeia 1991:695-702. Crossref

Huggins, R. M.

1989. On the statistical analysis of capture-recapture experiments. Biometrika 76:133-140. Crossref

1991. Some practical aspects of a conditional likelihood approach to capture experiments. Biometrics 47:725-732. Crossref

Hurvich, C. M., and C.-L. Tsai.

1989. Regression and time series model selection in small samples. Biometrika 76:297-307. Crossref

Ingram, E. C., and D. L. Peterson.

2018. Seasonal movements of shortnose sturgeon (Acipenser brevirostrum) in the Altamaha River, Georgia. River Res. Appl. 34:873-882. Crossref

Jenkins, W. E., T. I. J. Smith, L. D. Heyward, and D. M. Knott.

1993. Tolerance of shortnose sturgeon, Acipenser brevirostrum, juveniles to different salinity and dissolved oxygen concentrations. Proc. Annu. Conf. Southeast. Assoc. Fish Wildl. Agencies 47:476-484.
Kazyak, D. C., A. M. Flowers, N. J. Hostetter, J. A. Madsen, M. Breece, A. Higgs, L. M. Brown, J. A. Royle, and D. A. Fox.

2020. Integrating side-scan sonar and acoustic telemetry to estimate annual spawning run size of Atlantic sturgeon in the Hudson River. Can. J. Fish. Aquat. Sci. 77:1038-1048. Crossref

Kieffer, M. C., and B. Kynard.

1996. Spawning of the shortnose sturgeon in the Merrimack River, Massachusetts. Trans. Am. Fish. Soc. 125:179-186. Crossref

Kynard, B.

1997. Life history, latitudinal patterns, and status of the shortnose sturgeon, Acipenser brevirostrum. Environ. Biol. Fish. 48:319-334. Crossref

NMFS (National Marine Fisheries Service).

1998. Final recovery plan for the shortnose sturgeon (Acipener Brevirostrum), 104 p. Prepared by the Shortnose Sturgeon Recovery Team for the National Marine Fisheries Service, Silver Spring, MD. [Available from website.]

O'Herron, J. C., II, K. W. Able, and R. W. Hastings.

1993. Movements of shortnose sturgeon (Acipenser brevirostrum) in the Delaware River. Estuaries 16:235-240. Crossref

Peterson, D. L., and D. J. Farrae.

2011. Evidence of metapopulation dynamics in shortnose sturgeon in the southern part of their range. Trans. Am. Fish. Soc. 140:1540-1546. Crossref

Peterson, D. L., and M. S. Bednarski.

2013. Abundance and size structure of shortnose sturgeon in the Altamaha River, Georgia. Trans. Am. Fish. Soc. 142:1444-1452. Crossref

$\mathrm{R}$ Core Team.

2018. R: a language and environment for statistical computing. R Foundation for Statistical Computing, Vienna Austria. [Available from website, accessed August 2018.]

Scott, W. B., and E. J. Crossman.

1973. Freshwater fishes of Canada. Fish. Res. Board Can. Bull. 184, 966 p.

Secor, D. H.

2002. Atlantic sturgeon fisheries and stock abundances during the late nineteenth century. Am. Fish. Soc. Symp. 28:89-98.

Sheldon, J. E., and M. Alber.

2002. A comparison of residence time calculations using single compartment models of the Altamaha River estuary, Georgia. Estuaries 25:1304-1317. Crossref

SSSRT (Shortnose Sturgeon Status Review Team).

2010. Biological assessment of shortnose sturgeon (Acipenser brevirostrum), 417 p. Report to National Marine Fisheries Service, Northeast Regional Office, Gloucester, MA. [Available from website.]

Vine, J. R., S. C. Holbrook, W. C. Post, and B. K. Peoples.

2019. Identifying environmental cues for Atlantic sturgeon and shortnose sturgeon spawning migrations in Savannah River. Trans. Am. Fish. Soc. 148:671-681. Crossref

Vladykov, V. D., and J. R. Greeley.

1963. Order Acipenseroidei. In Fishes of the western North Atlantic. Part 3: soft-rayed bony fishes (V. H. Olsen, ed.), p. 24-60. Sears Found. Mar. Res., Yale Univ., New Haven, CT.

White, G. C., and K. P. Burnham.

1999. Program MARK: survival estimation from populations of marked animals. Bird Study 46:S120-S139. Crossref

Woodland, R. J., and D. H. Secor.

2007. Year-class strength and recovery of endangered shortnose sturgeon in the Hudson River, New York. Trans. Am. Fish. Soc. 136:72-81. Crossref 